\title{
REAKTUALISASI JIHAD FÎ SABÎL AL-LÂH \\ DALAM KONTEKS KEKINIAN \\ DAN KEINDONESIAAN
}

Muhammad Chirzin*

\section{Abstract}

Some moslems perceive the concept of jihad simply on the perspective of political ideology. Jihad is understood as fight againts external enemies. This leads to the meaning of jihad as a struggle using the power of weapon (war) againts the enemy of Islam. This makes it contraproductive for Indonesian moslems who live in pluralistic society.

Therefore, reinterpretation of the meaning of jihad is urgently needed to get a more contextual meaning in accordance with the Indonesian moslems circumtances. Refering to the classical literatures, the meaning of jihad, can be corrected to be more conceptual and practical. Jihad should contain a concept of collective struggle to overcome the actual problems faced by moslems such as economy, law, and education.

Keywords: Terorisme, Jihad Inklusif, Jihad Politik, Jihad Ekonomi, Jihad Pendidikan.

DALAM situasi peradaban global dewasa ini, Islam diidealisasikan dapat memberikan pembelaan dan sumbangan pencerahan terhadap peradaban modern yang sekuler-ateistis. Peradaban ini hampir telah "kehabisan nafas" untuk menawarkan sesuatu yang kukuh dan abadi untuk masa depan umat manusia. Jihad adalah salah satu pesan al-Quran dan hadis yang dilaksanakan muslim

*Penulis adalah dosen pada Fakultas Ushuluddin dan Program Pascasarjana UIN Sunan Kalijaga, Jln. Marsda Adi Sucipto Yogyakarta 55281. e-mail: mahmudi_jogja@yahoo.com. 
kapan saja dan di manapun berada. Nabi Muhammad saw. dan para sahabat berjihad, berdakwah menyebarluaskan Islam, mengajak berbuat kebajikan, dan mencegah serta menghentikan kejahatan dengan lisan, kekuatan fisik, maupun keteladanan.

Jihad semestinya diterapkan dalam kehidupan, sekaligus dijadikan solusi atas permasalahan yang berkembang dalam kehidupan. Jihad dilakukan terus-menerus untuk membebaskan manusia dari penghambaan terhadap segala sesuatu yang dapat merintangi manusia untuk menjadi homo sapiens. ${ }^{1}$ Dalam konteks kekinian dan keindonesiaan, jihad perlu diprioritaskan dalam bidang ekonomi, politik, dan hukum secara simultan.

\section{Jihad dalam al-Quran dan al-Sunnah}

Lafal jihad berasal dari kata dasar jahd yang artinya usaha, jerih payah, dan kesukaran. Kata jâhada-yujâhidu-mujâhadah-jỉhâd artinya berusaha sungguh-sungguh dengan mencurahkan jerih payah dalam rangka melaksanakan perintah Allah; berjuang. ${ }^{2}$ Ayat-ayat jihad dalam konteks perjuangan berjumlah 28, empat turun pada periode Makkah dan selebihnya periode Madinah. ${ }^{3}$ Dari ayat-ayat tersebut itu dapat dirumuskan bahwa jihad ialah perjuangan orang beriman dengan mencurahkan kemampuan moril dan materil berupa tenaga, pikiran maupun harta benda untuk menegakkan agama Allah dan meninggikan kalimat-Nya. ${ }^{4}$

${ }^{1}$ A. Syafi'i Ma'arif, Mencari Autentisitas dalam Kegalauan (Jakarta: PSAP Muhammadiyah, 2004), 67.

2Ibn Manzhûr, Lisân al-'Arab (Kairo: Dâr al- $\underline{H}$ adits, 2003), 239-41; Majma' al-Lughah al-'Arabiyyah, al-Mu'jam al-Wasith (Kairo: Maktabah alSyurûq al-Dawliyah, 2004), 142.

3Muhammad Fu'âd 'Abd al-Bâqî, Al-Mu'jam al-Mufahras li Alfâz̆h alQur'ân al-Karîm (Kairo: Dâr al- $\underline{H}$ adîts, 1991), 232-3. Ayat-ayat jihad periode Makkah yang dimaksud secara berurutan adalah Qs. al-Furqân (25): 52, Qs. al-Nahl (16): 110, Qs. al-'Ankabût (29): 6, Qs. al-'Ankabût (29): 69.

${ }^{4}$ Lihat Qs. al-Baqarah (2): 218; Qs. al-Mầidah (5): 35 dan 54; Qs. al-Anfâl (8):

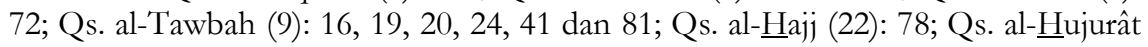
(49): 15; dan Qs. al-Shâff (61): 10-12. 
Pesan jihad dalam al-Quran meliputi lima komponen: tujuan, pelaku, sarana, sasaran, imbalan, dan sanksi. Tujuan jihad ialah mewujudkan ide-ide Islam dalam al-Quran dan al-Sunnah, yakni tegaknya kalimah al-Lâh; ${ }^{5}$ pelakunya adalah Rasulullah saw. dan orang-orang beriman; 6 imbalannya adalah memperoleh kebaikan, kemenangan dan kemuliaan di dunia, ampunan, dan surga penuh kebahagiaan di akhirat; ${ }^{7}$ adapun mereka yang tidak berjihad mendapat predikat fasik dan diancam neraka jahanam di akhirat. ${ }^{8}$ Setidaknya menurut al-Qur'an terdapat dua hal yang menjadi sasaran jihad ialah musuh-musuh Allah yang tampak: orang-orang kafir, musyrik, munafik, dan para pelaku kejahatan maupun musuh yang tak tampak, yakni setan dan hawa nafsu. ${ }^{9}$ Sarana jihad adalah harta dan jiwa-raga. Jihad dilakukan dengan perkataan maupun perbuatan, baik melalui lisan, tulisan, kekuatan fisik, maupun dengan membelanjakan harta benda. ${ }^{10}$

Menurut hadis Nabi Muhammad saw., jihad di jalan Allah termasuk amal yang paling disukai Allah swt. ${ }^{11}$ Bagi wanita pada masa Nabi Muhammad saw., dan jihad mereka paling utama adalah haji mabrur. ${ }^{12}$ Termasuk dalam kategori jihad ialah

${ }^{5}$ Lihat Qs. al-Baqarah (2): 218; Qs. Ali-'Imrân (3): 142; Qs. al-Anfâl (8): 74; Qs. al-'Ankabût (29): 62; Qs. al-Mumtahinah (60): 1.

${ }^{6}$ Lihat Qs. al-'Imrân (3): 142; Qs. al-Mâ'idah (5): 54; Qs. al-Anfâl (8): 75; Qs. alTawbah (9]: 24, 44, 86, 88; dan Qs. Muhammad (47): 31.

7Lihat Qs. al-Nisâ' (4): 95; Qs. al-Anfâl (8): 74; dan Qs. al-Tawbah (9): $20,41$.

${ }^{8}$ Lihat Qs. al-Tawbah (9): 24, 81.

'Lihat Qs. al-Mâ'idah (5): 35; Qs. al-Anfâl (8): 72; Qs. al-Tawbah (9): 41, 44, 73, 81; Qs. al-Furqân (25): 52; Qs. al-Ankabût (29): 6, 69; dan Qs. alTahrîm (66): 9.

${ }^{10}$ Lihat Qs. al-Nisâ' (4): 95; Qs. al-Anfâl (8): 72; Qs. al-Tawbah (9): 20, 41, 44, 81 dan 88; dan Qs. al- Hujurât (49): 15.

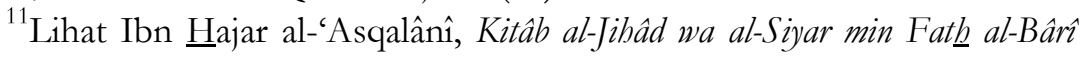
(Beirut: Dâr al-Balâghah, 1985), 11-2.

${ }^{12}$ Lihat Abû 'Abd Allâh al-Bukhârî, Shahîh Bu Bukhârî, jilid III (t.k: Dâr alMathba'ah al-Sya'bî, t.th.), 12. 
berjuang menghadapi orang-orang yang mengucapkan apa yang tidak dilakukan dan melakukan apa yang tidak diperintahkan, baik dengan tangan, lisan, maupun hati. ${ }^{13}$ Perang di jalan Allah adalah termasuk jihad. ${ }^{14}$ Adapun jihad yang paling disukai Allah ialah ucapan yang benar kepada penguasa yang lalim..$^{15}$

Jihad pada periode Makkah dilaksanakan Nabi Muhammad saw. dengan menyeru manusia ke jalan Allah bersenjatakan alQuran. ${ }^{16}$ Pada awal turunnya wahyu di Makkah, penekanan substansi wahyu tersebut banyak menyinggung tindakan yang bersifat persuasif. Nabi Muhammad saw. yang mengemban segenap fungsi kenabiannya memperingatkan orang-orang yang menyembah berhala, sekaligus mengajak mereka untuk menyembah Allah. Adapun jihad pada periode Madinah dilaksanakan dengan melanjutkan dakwah secara damai kepada penduduk Madinah.

Jihad berbentuk perang diizinkan Allah pada tahun kedua hijrah, ${ }^{17}$ dan peperangan pertama kali antara kaum muslimin dengan kaum Quraisy terjadi di Badr, sebuah desa, yang merupakan pangkalan air di antara Madinah dan Makkah, pada pagi hari tanggal 17 Ramadhan $2 \mathrm{H} / 12$ Maret 624 M.18 Di bawah pimpinan Nabi Muhammad saw., komunitas muslim yang kecil harus berijhad habis-habisan, mengerahkan segala daya dan upaya, sebab perang itu sangat menentukan hari depan

${ }^{13}$ Lihat Abû Husayn Muslim, Shaḅ̂hㅡ Muslim, ter. AD Hanie (Yogyakarta: Penyiaran Islam, 1962), 47-8.

${ }^{14}$ Bukhârî, Sha $\underline{h} \underline{\underline{h}}$...., jilid III, 201.

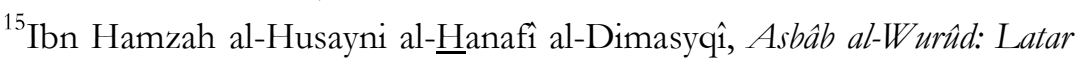
Belakang Historis Timbulnya Hadis-hadis Rasul, ter H.M Suwarta Wijaya (Jakarta: Kalam Mulia, 1997), 51.

${ }^{16}$ Lihat Qs. al-Furqân (25):52.

${ }^{17}$ Lihat Qs. al- $\underline{\mathrm{H}}$ ajj (22): 39-40.

${ }^{18}$ Muhammad Husain Haekal, Sejarah Hidup Muhammad, ter. Ali Audah (Jakarta: Pustaka Jaya, 1980), 262-95, Majid Ali Khan, Muhammad saw. Rasul Terakhir, ter. Fathul Umam (Bandung: Pustaka, 1985), 127. 
mereka. Peristiwa Badar telah menjadi salah satu pilar utama sebagai realisasi doktrin jihad guna menopang perkembangan Islam selanjutnya untuk tampil sebagai agama dunia dengan misi membangun peradaban manusia di muka bumi.

\section{Pandangan Pakar tentang Jihad}

Beberapa ulama dan pakar dari masa ke masa telah berusaha merumuskan pengertian jihad. Menurut Ibn Manzhûr, jihad ialah memerangi musuh, mencurahkan segala kemampuan dan tenaga berupa kata-kata, perbuatan atau segala sesuatu yang seseorang mampu. ${ }^{19}$ Menurut al-Jurjânî dalam al-Ta'rifât, jihad ialah seruan kepada agama yang benar. ${ }^{20}$ Sedangkan menurut al-Asfahânî jihad ialah mencurahkan kemampuan menahan musuh; berjuang menghadapi musuh yang tampak, setan dan hawa nafsu. ${ }^{21}$ Menurut pendiri Ikhwân al-Muslimîn, jihad adalah kewajiban muslim yang berkelanjutan hingga hari kiamat; tingkat terendahnya penolakan keburukan dengan hati dan tertinggi perang di jalan Allah. Di antara keduanya perjuangan dengan lisan, pena dan tangan; menyatakan kebenaran di depan penguasa zalim. ${ }^{22}$

Dari kalangan ulama fiqih, Sayyid Sabiq mendefinisikan jihad sebagai meluangkan segala usaha dan upaya dengan menanggung kesulitan dalam memerangi musuh dan menahan agresi. ${ }^{23}$ Wahbah al-Zuhaylî, seorang mufasir dan ulama fikih menulis

\footnotetext{
${ }^{19}$ Manzhûr, Lisân..., 521.

${ }^{20}$ al-Jurjânî, Al-Ta'rifât (t.k:t.p, 1938), 70.

${ }^{21}$ al-Râghib al-Asfahânî, Mu'jam al-Mufradât Alfâz’̧ al-Qur'ân (t.k: t.p., t.th.), 100.

${ }^{22}$ Yusuf Qardhawi, Pendidikan Islam dan Madrasah Hasan al-Banna, ter. Bustami A. Gani dan Zainal Abidin Ahmad (Jakarta: Bulan Bintang, 1980), 74.

${ }^{23}$ Sayyid Sabiq, Fikih Sunnah, ter. Kamaluddin A. Marzuki (Bandung: AlMâ'arif, 1987), 50.
} 
bahwa jihad ialah mencurahkan daya upaya memerangi orang kafir dengan jiwa, harta dan lisan. ${ }^{24}$ Pemikir muslim kontemporer Farid Esack merumuskan jihad sebagai perjuangan, mencurahkan daya upaya untuk melakukan transformasi pada tataran individu dan masyarakat. ${ }^{25}$ Munawar Ahmad Anees mendefinisikan jihad sebagai perjuangan terus-menerus secara individual dan komunal ke arah pembangunan dan peningkatan menurut struktur dan kerangka nilai Islam untuk mewujudkan ideal-ideal yang tercantum dalam al-Quran dan sunnah Nabi Muhammad saw. yang merupakan konsep holistik bagi rekonstruksi sosial di mana anggota masyarakat terlibat dalam aksi positif untuk memperbaiki masyarakat. ${ }^{26}$

Dari pendapat para pakar tersebut dapat disimpulkan bahwa jihad adalah perjuangan orang beriman secara individual maupun komunal, dengan mencurahkan segala kemampuan, moril maupun materiil berupa tenaga, pikiran maupun harta untuk menegakkan agama dan kalimat-Nya. Jihad dilakukan di masa damai dan perang.

\section{Jihad, Terorisme, dan Bom Bunuh Diri}

Islam mengatur hubungan antarmanusia berdasarkan interaksi terus-menerus, saling membantu, memerangi kekerasan, dan terorisme. ${ }^{27}$ Terorisme merupakan tindakan

${ }^{24}$ Wahhbah al-Zuhaylî, al-Figh al-Islâmî wa Adillatubu (Damaskus: Dâr alFikr, 1989), 413.

${ }^{25}$ Farid Esack, Quran, Liberation, and Pluralism (Oxford: Oneworld, 1997), 107.

${ }^{26}$ Munawar Ahmad Anees dalam Ziauddin Sardar dan Merryl Wyn Davis (ed.), Wajah-wajah Islam, ter. A.E. Priono dan Ade Armando (Bandung: Mizan, 1992), 107.

${ }^{27} \mathrm{Hal}$ itu tergambar dalam ajaran fundamental berikut; pertama, setiap manusia dengan segala perbedaannya, di mata Islam adalah makhluk mulia dan utama dibandingkan makhluk lainnya (Qs. al Isrâ' [17]: 70); kedua, pluralitas manusia dan perbedaan adalah nikmat, dan bukan suatu 
represif terhadap jiwa, fisik, dan harta dengan menggunakan kekerasan yang bertujuan untuk menyakiti atau memaksa individu, masyarakat, lembaga tertentu, untuk mengambil sebuah keputusan dan mendapatkan sebuah perlakuan tertentu, atau dengan maksud mengikuti tujuan politis yang dianggap benar oleh pihak pelaku. Gerakan radikal dan terorisme sering kali tumbuh subur dan berkembang dalam tiga lingkungan. Pertama, lingkungan di mana kesempatan untuk menikmati demokrasi sangat terbatas. Kedua, lingkungan di mana keadilan sosial tidak terwujud dan kesenjangan antara yang kuat, pemilik modal dan kaya dengan kaum lemah dan miskin sangat lebar. Kondisi tersebut diperparah dengan subordinasi yang harus mereka terima dalam mendapatkan hak-hak secara sah. Ketiga, lingkungan tanpa supremasi hukum dan banyak pelanggaran atas hak-hak dasar individu dalam kasus-kasus berkaitan dengan tuduhan dan vonis yang disertai tindakan represif dan penyiksaan, sehingga melahirkan keinginan untuk memberontak dari hukum dan masyarakat secara keseluruhan.

Apabila orang mengaitkan Islam dengan terorisme, maka itu bertentangan dengan fakta sejarah. Peranan Islam dalam mendukung gerakan pembebasan dari penjajahan berjalan seiring dengan gerakan lain untuk menjaga kemurnian dan independensi kultural serta menanamkan kesadaran pada umat, bahwa mereka memiliki kultur tersendiri yang berbeda dari lainnya. Seterusnya, timbul kesadaran dalam nalar bangsa Barat pada umumnya bahwa Islam adalah musuh utama yang melahirkan dan menggerakkan permusuhan terhadap Barat, dan

penghalang (Qs. al- Hujurât [49]: 13); ketiga, darah atau jiwa dan harta manusia dilindungi, baik muslim maupun nonmuslim (Qs. al-Anfâl [8]: 72); keempat, perang dilakukan demi mewujudkan perdamaian dan cinta manusia serta tidak boleh melanggar batasan etis dan normatif, Ahmad Kamal Abu Majd, "Islam dan Tatanan Dunia Global: Terorisme atau Humanisme?" prolog dalam Zuhairi Misrawi dan Khamami Zada, Islam Melawan Terorisme (Jakarta: LSIP, 2004), 19-21. 
kaum muslim dianggap sebagai salah satu sumber bahaya bagi peradaban Barat seluruhnya. ${ }^{28}$

Faktor lain yang menyebabkan munculnya kesalahpahaman terhadap Islam dalam hubungannya dengan terorisme adalah munculnya beberapa gerakan dan partai atau kelompok yang mengusung simbol-simbol dan jargon-jargon Islam, bahkan dengan pola-pola yang bertentangan dengan norma masyarakat, dan bergerak di luar jalur legal. Kelompok-kelompok tersebut mengesahkan intimidasi, kekerasan, dan pembunuhan atas musuh-musuhnya.

Ketika aksi terorisme meluas melintasi batas negara, dan akumulasinya bertambah, cukup rasional adanya upaya bersama dari masyarakat internasional untuk melawannya dengan memberi definisi yang disepakati bersama. Namun upaya mencapai kesepakatan tentang definisi terorisme menemukan jalan buntu, yang menggambarkan banyaknya konflik politik dan kepentingan yang ada di balik aksi dan isu terorisme.

Teroris bukan saja bekerja di luar konsep jihad dalam Islam, tetapi juga merusak bumi dan peradaban. ${ }^{29}$ Secara nalar umum maupun logika hukum dan tujuan syariat, jihad dengan menggunakan teror, termasuk bom bunuh diri mengindikasikan sifat manusia yang putus asa, hilang akal sehat dan merusak martabat Islam sebagai agama kedamaian. ${ }^{30}$ Terorisme adalah terorisme, suatu kejahatan kemanusiaan, siapa pun yang melakukannya, tetapi perjuangan mempertahankan hak dan kehormatan adalah perjuangan, suatu kepahlawanan kemanusiaan, siapa pun yang melakukannya. ${ }^{31}$

${ }^{28}$ Misrawi dan Zada, Islam ..., 11.

${ }^{29}$ Jawahir Thonthowi, Islam, Neo Imperialisme dan Terorisme Perspektif Hukum Internasional dan Nasional (Yogyakarta: UII Press, 2004), 22.

${ }^{30}$ Ibid., 23.

${ }^{31}$ Demikian pendapat Nurcholish Madjid seperti dikutip Idi Subandy Ibrahim dan Asep Syamsul M. Romli dalam Kontroversi Ba'asyir: Jihad Melawan Opini Fitnah Global (Bandung: Nuansa, 1998), 8. 


\section{Konteks Kekinian Umat Islam}

Masa depan Indonesia adalah masa depan umat Islam. Aspirasi umat Islam "sebangun” dengan aspirasi bangsa. Bangsa ini harus bisa mencapai kesejahteraan dan memajukan masyarakatnya. Jika tidak, maka yang akan menderita umat Islam sendiri; umat Islam perlu berperan lebih besar di negara ini. Mereka harus memerankan diri sebagai agen dari berbagai perubahan. Mereka harus berada di baris depan untuk mengamati kecenderungan sejarah di Indonesia. Mereka berhak dan harus menyatakan sikap terhadap kecenderungankecenderungan yang sedang berlangsung. Misalnya, semakin dominannya sistem kapitalisme di Indonesia. Apabila umat Islam tidak setuju terhadap kecenderungan tersebut, mereka perlu menolak dan mengatakan "tidak" di garis depan. Sebab, kalau umat Islam hanya berada di pinggiran, mereka akan menjadi objek perubahan yang terjadi. Mereka niscaya berperan di semua sektor.

Umat Islam Indonesia menghadapi fenomena pluralitas agama. Pluralitas merupakan conditio sine qua non dalam penciptaan makhluk. Pluralitas berfungsi sebagai pendorong untuk saling berkompetisi dalam melakukan kebaikan, berlomba menciptakan prestasi dan sebagai motivator yang memberikan tuntunan bagi perjalanan bangsa-bangsa pemilik peradaban dalam menggapai kemajuan dan ketinggian. Pandangan pluralistik tidak menafikan realitas yang bersifat partikularistik dengan bagian-bagiannya yang mempunyai keunikan. ${ }^{32}$ Pluralisme tidak sama dengan relativisme, sinkretisme, dan peleburan budaya. ${ }^{33}$ Pluralisme mengandung pengakuan dan penerimaan atas keberbedaan dan keragaman, baik di antara

\footnotetext{
${ }^{32}$ M. Amin Abdullah, Dinamika Islam Kultural: Pemetaan Atas Wacana Keislaman Kontemporer (Bandung: Mizan, 2000), 71.

${ }^{33}$ Kuntowijoyo, Identitas Politik Umat Islam (Bandung: Mizan, 1997), 1557.
} 
sesama maupun pada penganut agama lain. ${ }^{34}$ Pluralitas mempunyai tingkatan-tingkatan yang ditentukan oleh faktor penyatu dan pengikat dalam satu kesatuan. Masing-masing individu dalam pluralitas tersebut mempunyai perbedaan dalam kekhasan yang seluruhnya bertemu dalam ikatan peradaban yang satu, yaitu peradaban manusia yang merangkumnya. ${ }^{35}$

Piagam Jakarta mencerminkan aliran-aliran Islam, Nasionalis, dan Kristen serta merupakan pencerminan hasrat bangsa Indonesia untuk memerdekakan tanah airnya. Piagam Jakarta menggambarkan persatuan bangsa Indonesia yang pluralistik dalam satu cita-cita kemerdekaan dan dalam perjuangan bersama-sama mengusir penjajah, tanpa pembedaan suku bangsa, ras, dan agama. Kehidupan beragama membutuhkan toleransi sebagai prasyarat terciptanya kerukunan, dialog, dan kerjasama. Bangsa Indonesia telah memiliki landasan konstitusionil untuk menciptakan kehidupan beragama yang toleran. 36

Umat Islam memiliki panduan dalam al-Quran untuk hidup beragama dalam masyarakat yang menggariskan tentang kemerdekaan beragama. ${ }^{37}$ Umat Islam memerlukan konsep baru

${ }^{34}$ Farid Esack, Quran, Liberation and Pluralism: An Islamic Perspective of Interreligious Solidarity Against Oppression (Oxford: Oneworld, 1997), xii.

${ }^{35}$ Muhammad Imarah, Islam dan Pluralitas: Perbedaan dan Kemajemukan dalam Bingkai Persatuan (Jakarta: Gema Insani Press, 1999), 9-10.

${ }^{36}$ Undang-undang Dasar RI 1945 pasal 29 menyatakan: (1) Negara berdasarkan atas Ketuhanan Yang Maha Esa. (2) Negara menjamin kemerdekaan tiap-tiap penduduk untuk memeluk agamanya masing-masing dan untuk beribadat menurut agama dan kepercayaannya itu.

${ }^{37}$ Ayat-ayat yang paling populer untuk masalah ini ialah Qs. al-Baqârah (2): 256 dan Qs. Yûnus (10): 99-100, yang artinya: “Tidak ada pemaksaan dalam soal agama. Jelas bedanya yang benar daripada yang sesat. Barang siapa menolak Setan dan beriman kepada Allah, ia telah berpegang teguh dengan genggaman tangan yang tidak akan lepas. Dan Allah Maha Mendengar, Maha Tahu; Jika Tuhanmu menghendaki, niscaya semua 
hubungan antarumat beragama yang bersifat keluar dan tidak asyik dengan diri sendiri saja, melihat ke depan dengan bersamasama menghadapi masa depan kemanusiaan yang dinamis dan merujuk pada kerja. Oleh sebab itu, umat beragama hendaknya dapat membuat agenda nasional bersama, seperti masalah pembangunan, keadilan, kemiskinan, keterbelakangan, maupun agenda global, seperti tantangan modernitas, alienasi, spiritualisme, dan nilai-nilai kemanusiaan pada umumnya.

Kerjasama intern dan antarumat beragama menuntut kejujuran dari masing-masing pihak. Untuk menuju toleransi antarumat beragama, lebih dahulu niscaya dibangun kehidupan yang toleran interen umat beragama. Di lingkungan umat Islam sendiri tidak boleh memandang satu sama lain dalam pola-pola yang absolutistik. Selanjutnya memperluas sikap tersebut ke golongan dan agama-agama yang lain, bahwa agama-agama lain itu berhak untuk hidup, bahkan harus dilindungi. Islam mendasarkan hubungan umatnya dengan umat beragama lain atas prinsip koeksistensi damai. ${ }^{38}$ Kerukunan antarumat beragama itu diharapkan bukan sekadar koeksistensi, tapi kooperasi. Hal ini bukan pengakuan bahwa agama-agama lain itu benar, tetapi pengakuan akan hak dari setiap agama untuk eksis di dalam hubungan sosial yang toleran, saling menghargai, saling membantu, menghormati dan sebagainya tanpa mengorbankan keyakinan akan kebenaran agamanya sedikit pun. Inklusivisme memberikan ruang seluas-luasnya untuk kerukunan, dialog, integrasi dan kerjasama antar-umat beragama yang mengarah pada sikap dan pandangan hidup pluralisme. ${ }^{39}$ Hak setiap orang

manusia yang ada di bumi beriman seluruhnya. Hendak kau paksa jugakah orang supaya beriman? Dan orang tidak akan beriman kecuali dengan izin Allah juga dan Ia menanamkan keraguan [atau kekaburan] pada mereka yang tidak menggunakan pikiran (Qs. Yûnus [10]: 99-100).

${ }^{38}$ Majelis Tarjih PP Muhammadiyah, Tafsir..., 36.

${ }^{39}$ Sukidi, Teologi ..., 7 . 
untuk yakin bahwa agamanyalah yang benar, tetapi pada saat yang sama dia harus menghormati orang lain untuk bersikap sama.

Pemahaman jihad yang inklusif membuka kesadaran keberagamaan yang lapang, egaliter, dan terbuka yang dapat menjadi jalan untuk merealisasikan Islam sebagai rabmatan lil'alamin; bekerja sama dengan umat-umat beragama lain untuk menegakkan jaminan dasar yang diberikan Islam dan menjadi tujuan pokok ajaran agama. ${ }^{40}$ Adapun pemahaman jihad yang eksklusif menghambat kemungkinan mendapatkan salingpengertian antaragama yang menjadi obsesi kultural bangsa Indonesia serta mengingkari realitas kemajemukan masyarakat Indonesia. ${ }^{41}$

Sebagai warga negara, umat Islam berhak untuk memilih sistem yang benar. Jika sistem yang ada acceptable, tentu umat Islam bisa menerimanya. Tetapi jika sistem yang ada dianggap belum acceptable, tentu harus ada usaha untuk memperbaikinya. Oleh karena itu, saluran agar mereka bisa ikut "bersuara" juga perlu diperjuangkan dan semua orang mempunyai hak untuk ini. Adalah suatu kelengahan umat Islam dalam bernegara bila undang-undang atau hukum positif yang berlaku bagi rakyat Indonesia yang hampir $90 \%$ memeluk agama Islam hanya sedikit saja yang mencerminkan nilai ajaran Islam. ${ }^{42}$

${ }^{40}$ Abdurrahman Wahid, "Universalisme Islam dan Kosmopolitanisme Peradaban Islam" dalam Budhy Munawar-Rahman (ed.), Kontekstualisasi Doktrin Islam dalam Sejarah (Jakarta: Paramadina, 1994), 546 dan M. Quraish Shihab, Membumikan Al-Quran (Bandung: Mizan, 1992), 368.

${ }^{41}$ Budhy Munawar-Rahman, Islam Pluralis: Wacana Kesetaraan Kaum Beriman (Jakarta: Paramadina, 2001), xiii.

${ }^{42}$ Menurut Sukarno, badan perwakilan merupakan tempat yang terbaik untuk memelihara agama, tempat untuk mengemukakan tuntutan-tuntutan Islam bagi perbaikan. Umat Islam harus bekerja sehebat-hebatnya agar sebagian terbesar kursi-kursi badan perwakilan rakyat diduduki oleh utusanutusan Islam. Jika $90 \%$ utusan yang duduk dalam perwakilan rakyat itu 


\section{Jihad di Indonesia Masa Kini}

Jihad yang diperlukan pada masa kini ialah perjuangan menegakkan kebenaran dan melawan kebatilan dengan argumentasi dan penjelasan, kekuatan dan kekuasaan tahap demi tahap secara berkesinambungan dengan dukungan media sesuai kebutuhan untuk merealisasikan kebaikan dan perkembangan pada manusia, dengan berhimpun dalam pergerakan konkret menurut keadaan yang melingkupinya. Kenyataan menunjukkan bahwa gerakan amar ma'ruf nabi munkar selalu menghadapi gerakan pihak lain yang ber-amar munkar nabi ma'ruf. Orang sekarang menyebarkan kemungkaran dengan organisasi canggih, apakah itu di bidang perjudian atau pergaulan bebas. Agenda jihad atau perjuangan umat Islam bersama masyarakat Indonesia masa kini meliputi bidang ekonomi, politik, hukum, dan pendidikan yang sesungguhnya saling berkait satu dengan yang lain. ${ }^{43}$

Pertama, jihad di bidang ekonomi. Secara teoretis, ekonomi adalah cara manusia memenuhi kebutuhannya. ${ }^{44}$ Tiap-tiap kelompok manusia dan tiap bangsa mempunyai cara masingmasing. Setiap bangsa dan negara mempunyai pilihan sesuai dengan jiwa dan falsafah mereka. Bangsa Indonesia pun dihadapkan kepada persoalan pilihan itu: cara atau pengaturan ekonomi mana yang akan dipakai bangsa Indonesia? Pada titik ini ekonomi sudah berpautan dengan hukum, sebab soal pilihan

orang Islam, pemuka-pemuka Islam, dengan sendirinya hukum-hukum yang keluar dari badan perwakilan rakyat itu hukum Islam pula. Lihat Soekarno, Tjamkan Pantja Sila! Pantja Sila Dasar Falsafah Negara (Djakarta: Pradnja Paramita, 1964), 27-8.

43 Jihad di bidang pendidikan memerlukan ruang pembahasan tersendiri. Untuk memahami pro dan kontra Ujian Nasional dapat diikuti tulisan Utomo Dananjaya, "Paradigma Pendidikan dan Pendapat Penguasa" dan Jc Tukiman Taruna, "Pendongkrak Mutu?" dalam Kompas, Senin, 15 Mei 2006, 14.

${ }^{44}$ Ismail Saleh, Hukum dan Ekonomi (Jakarta: Gramedia, 1990), ix. 
hidup bersama ini tidak semata-mata soal motif ekonomi, tetapi juga menyangkut soal hukum. Bahkan pada keadaan demikian hukum mempunyai posisi yang kuat: hukum menentukan arah mana yang akan ditempuh dan bagaimana cara menempuh arah ini. Antara ekonomi dan hukum berkaitan erat di mana yang satu dengan yang lain saling mempengaruhi. Sejarah pertumbuhan ekonomi dan perkembangan hukum di seluruh dunia menunjukkan hal itu, suatu perkembangan ekonomi akan mempengaruhi peta hukum. Sebaliknya, perubahan hukum juga akan memberikan dampak yang luas terhadap ekonomi. Deregulasi yang dilaksanakan pemerintah memberikan dampak yang luas dalam perekonomian nasional. ${ }^{45}$

Prinsip-prinsip ekonomi yang ideal masih belum dapat diterapkan. Berbagai penyimpangan dan pelanggaran terjadi di sana-sini. Keinginan pemerintah untuk segera memperbesar kue nasional dengan mendorong secara tanpa batas konglomerasi itu sangat buruk. Logika kapitalisme, baik yang terselubung maupun yang terbuka sama saja; yang besar makan yang kecil, yang lebih besar menekan yang kurang besar, sehingga terjadilah akumulasi kapital di sejumlah tangan. Itulah yang menimbulkan sejumlah kerawanan sosial politik yang besar dan di luar kendali.

Perjuangan di bidang ekonomi sangat banyak yang perlu diagendakan. Mengingat modus operandi penyelewengan dan penyimpangan di bidang ekonomi dari waktu ke waktu selalu meningkat dan berkembang, maka cara mengatasi dan memecahkannya pun harus dikembangkan dan ditingkatkan pula. Hal itu memerlukan sumbangan semua pihak dengan mencurahkan waktu, tenaga dan pikiran demi tegaknya cita-cita ekonomi bangsa. Pembangunan ekonomi tidak akan berhasil tanpa didahului oleh tegaknya hukum. Hukum dengan demikian menjadi fondasi bagi keberhasilan pembangunan ekonomi. Namun fondasi hukum tidak akan kuat bila situasi politik tidak

$$
{ }^{45} \text { Ibid., xi. }
$$


stabil. Stabilitas politik hanya bisa tercapai dengan berkembangnya demokrasi. Oleh karena itu reformasi di bidang politik, ekonomi, dan hukum harus dilaksanakan secara serentak. Dari sudut peraturan perundang-undangan reformasi politik dan ekonomi, pada awalnya dimulai dari pembaruan peraturan perundang-undangannya juga. 46

Kedua, jihad di bidang politik, haruslah dimulai dari penegakan demokrasi sambil tetap menjaga persatuan bangsa dan keutuhan negara RI. Partisipasi politik yang sejati dari semua lapisan warga negara harus dibangun kembali melalui tatanan politik yang demokratis, karena selama pemerintahan Orde Baru tatanan politik yang ada telah membungkam kreativitas politik masyarakat. ${ }^{47}$ Sungguhpun peraturan dan perundang-undangan telah dibuat demikian rupa, hal itu tidak otomatis menyelesaikan berbagai problem politik di Indonesia. Penerapan paradigma rasionalitas belum sanggup menuntun bangsa Indonesia keluar dari pelbagai problem dan konflik politik yang berkepanjangan. Aturan main yang jelas dan mengikat belum dapat menyelamatkan bangsa dari pelbagai krisis multi dimensi. Tanpa moralitas penegak hukum tidak sanggup menegakkan keadilan yang dinantikan oleh bangsa Indonesia. ${ }^{48}$

Dikotomi antara norma-norma moral dan norma-norma hukum dalam bidang politik hingga kini masih menjadi masalah kontroversial yang mengundang perdebatan. Pelanggaran atas sejumlah aturan moral perlu dikenai sanksi yuridis, seperti mereka yang melakukan pemerkosaan, tindak kekerasan, korupsi dalam skala apa pun, dan pelanggaran hak-hak dasar orang lain. ${ }^{49}$

\footnotetext{
${ }^{46}$ A.W. Pratiknya (et.al.), Pandangan dan Langkah Reformasi B.J. Habibie (Jakarta: PT RajaGrafindo Persada, 1999), 28.

${ }^{47}$ Ibid., 29-30.

${ }^{48}$ William Chang, "Konsensus Rasional atas Masalah Moral”, Kompas, 29 Mei 2002, 4.

${ }^{49}$ Ibid.
} 
Letak daya himbauan moral dalam menghadapi masalah sosial bangsa Indonesia; pertama, bahwa moralitas pada dasarnya menawarkan suatu sistem prinsip-prinsip dan nilai-nilai yang terkait dengan perilaku manusia, yang umumnya diterima suatu masyarakat atau oleh suatu kelompok tertentu. Kedua, masyarakat Indonesia masih kurang memiliki rational consensus terhadap rentetan masalah moral yang sedang terjadi. Kasuskasus sosial, ekonomi dan politik di Indonesia bermula dari perilaku penguasa dan warga negara yang melupakan pentingnya penegakan nilai-nilai moral dasar dalam hidup bersama, seperti keadilan, kejujuran, kebenaran dan keberanian moral. Nilai-nilai itu sebagai tiang hidup bersama diabaikan. Akibatnya, korupsi, penginjakan hak-hak dasar manusia, dan pembohongan publik masih dilakukan sejumlah orang yang kebetulan sedang mengatur negara ini. ${ }^{50}$

Kasus-kasus korupsi, penjarahan kekayaan negara, dan pelanggaran nilai-nilai dasar manusia menunjukkan bahwa kewajiban moral tidak diperhatikan dan tidak dilaksanakan sebagaimana mestinya. Seorang penegak hukum positif yang tidak berniat dan berkehendak baik untuk menegakkan keadilan dalam tugas, berperan sebagai "pemain sandiwara" di atas "panggung" pengadilan. Selain sistem, manusia adalah salah satu sumber pemicu krisis berkepanjangan. Penanganan masalahmasalah sosial, ekonomi, dan politik menantikan orang-orang yang tidak hanya pintar, tetapi pribadi-pribadi yang juga bermoralitas tinggi guna memperbaiki keadaan ini. Kepintaran dan penggunaan akal budi yang sehat tidak dengan sendirinya identik dengan menerapkan nilai-nilai moral dalam penanganan proses-proses ekonomi, sosial, dan politik. Hukum positif dan aturan permainan memang penting. Namun, yang tidak kalah penting ialah moralitas orang-orang yang ditugaskan untuk

$$
{ }^{50} \text { Ibid., } 5 .
$$


menegakkan hukum dan aturan permainan, supaya hukum dan aturan itu tidak dipermainkan begitu saja. ${ }^{51}$

Ketiga, jihad di bidang hukum. Hukum adalah skema yang dibuat untuk menata perilaku manusia, tetapi manusia itu sendiri cenderung terjatuh di luar skema yang diperuntukkan baginya. Maka jihad dalam bidang hukum di Indonesia perlu menaruh perhatian saksama terhadap perilaku bangsa. ${ }^{52}$ Hukum merupakan wadah dan sekaligus isi dari peristiwa penyusunan diri kemerdekaan kebangsaan Indonesia atau kekuasaan kedaulatannya itu. Ia menjadi dasar bagi kehidupan kenegaraan Bangsa dan Negara Indonesia. 53

Penegakan hukum di Indonesia dewasa ini merupakan agenda perjuangan yang serius. Masalah penyalahgunaan kekuasaan, korupsi, dan suap-menyuap hingga kini merupakan masalah yang menonjol dan menuntut penanganan yang sungguh-sungguh. "Memberantas penyalahgunaan kekuasaan merupakan satu perjuangan yang berat dan memakan waktu". ${ }^{54}$ Fenomena sosial menunjukkan bahwa korupsi di sekitar kekuasaan ternyata kian marak saja. Mereka merasa memiliki hak untuk mendapatkan upeti atas kekuasaannya. Sakralisasi kekuasaan menjadi tempat berlindung yang aman bagi penguasa atas kelemahan dirinya. 55

Di mana pun, senantiasa terdapat kecenderungan pejabat tinggi negara yang tersangkut perkara korupsi sulit dijerat hukum. Terlebih-lebih bila pejabat tersebut tengah menduduki

${ }^{51}$ Ibid.

${ }^{52}$ Satjipto Rahardjo, "Hukum Itu Perilaku Kita Sendiri”, Kompas, 23 September 2002, 4.

${ }^{53}$ Ibid., 66.

${ }^{54}$ Dikutip oleh Majalah Intisari Nomor 216, Juli 1981, 169 dari Kompas, 12 Oktober 1967.

${ }^{55}$ Musa Asy'arie, "Konstitusi dan Kemandekan Budaya Politik", Kompas, 24 September 2002, 4. 
posisi strategis. Berbagai macam power yang dipegangnya akan menjadi batu sandungan serius bagi penegakan hukum atas dirinya. ${ }^{56}$ Dakwaan korupsi memiliki kesamaan prinsipil, yakni bahwa tindak pidana yang didakwakan tersebut berkaitan erat dengan jabatan yang disandang tatkala kejahatan itu dilakukan. Jabatan yang mengandung sejumlah power and authority (kekuasaan dan kewenangan) menjadi instrumen utama dimungkinkannya kejahatan yang dituduhkan itu dapat dilaksanakan pelaku. Dominannya peran jabatan dalam tindak pidana ini, menyebabkan pelaku tindak pidana korupsi tergolong sulit dilacak secara yuridis dibandingkan dengan rata-rata pelaku tindak pidana lain. Dengan kekuasaan itu, korupsi yang dilakukan dapat "dibungkus" dengan kebijakan yang sah, sehingga dari segi hukum dapat dinilai sebagai bagian dari pelaksanaan fungsi jabatan resmi. ${ }^{57}$ Di era Orde Reformasi dan pasca Orde Reformasi, korupsi, kolusi, suap, dan nepotisme tetap hidup dan berkembang. Akibatnya, harta republik menjadi barang jarahan. Belum ada tindakan yang sungguh-sungguh untuk melawan semua itu, padahal itulah yang membuat negeri ini terpuruk hingga sekarang. Sudah waktunya hal itu menjadi musuh bersama. Tidak ada kompromi bagi semua perilaku berbau korupsi.

Keengganan Bagir Manan menjadi saksi dalam sidang pengadilan tindak pidana korupsi atau sidang pengadilan tipikor dalam kasus suap menunjukkan sikap kurang patuh hukum, karena nama Bagir tercantum dalam berita acara pemeriksaan dan surat dakwaan jaksa penuntut umum, yang otomatis perlu ada konfirmasi dan klarifikasi dari Bagir dalam sidang pengadilan. Penghentian proses peradilan Soeharto merupakan tindakan berdasar perikemanusiaan yang beradab, tetapi tidak

${ }^{56}$ TB Ronny Rahman Nitibaskara, "Super White Collar Crime", Kompas, 1 Oktober 2002, 4.

${ }^{57}$ Ibid. 
adil. Penggundulan hutan di berbagai pulau Nusantara dan pengerukan isi perut bumi dan laut oleh mesin ekonomi-politik yang dikemudikan Soeharto adalah perbuatan kriminal. Penyiksaan manusia dalam sel-sel Orde Baru dan penghilangan tanpa jelas politisi dan aktivis mahasiswa adalah tindakan penghancuran hidup manusia yang tak terperikan. Penghentian proses peradilan Soeharto menjadi contoh dari penghentian penegakan sila perikemanusiaan yang adil dan beradab secara utuh, dan dapat dimaknai sebagai upaya penghalangan penegakan keadilan, mengekalkan ketakterjamahan hukum dan pengingkaran janji pemilu pasangan SBY-JK yang saat itu merayu calon pemilih dengan slogan: Aman, Sejahtera, dan Adil. Penyunatan dalam penerapan [sila kedua] Pancasila cukup menjadi alasan konstitusional yang sah untuk pengguliran proses impeachment, pemecatan Presiden dan Wakil Presiden. ${ }^{58}$

\section{Catatan Akhir}

Melalui tulisan di atas, dapat ditegaskan bahwa dalam konteks kekinian, konsep jihad idealnya dimaknai tidak hanya dari perspektif ideologi politik semata. Lebih naif lagi, jika dimaknai sebagai bentuk perjuangan dengan mengunakan kekerasan bersenjata an sich. Oleh karena itu, reinterpretasi makna jihad sangat mendesak dilakukan untuk mendapatkan makna yang lebih ramah, beradab, dan kontekstual.

Dalam konteks negara Indonesia modern, reaktualisasi jihad dapat dilakukan dalam ranah politik, ekonomi, hukum dan pendidikan. Keempat hal ini, sesunggguhnya saling berkaitkelindan satu sama lain, dan menjadi agenda dan proyek jihad kolektif umat Islam bersama dengan masyarakat Indonesia lainnya. Wa al-Lâh a lam.

${ }^{58}$ Tamrin Amal Tomagola, "Berperikemanusiaan, tetapi Tidak Adil", Kompas, Senin, 15 Mei 2006, 6. 


\section{Daftar Pustaka}

A. Syafi'i Ma'arif, Mencari Autentisitas dalam Kegalauan (Jakarta: PSAP Muhammadiyah, 2004).

A.W. Pratiknya (et.al.), Pandangan dan Langkah Reformasi B.J. Habibie (Jakarta: PT RajaGrafidno Persada, 1999).

Abdurrahman Wahid, "Universalisme Islam dan Kosmopolitanisme Peradaban Islam" dalam Budhy Munawar-Rahman (ed.), Kontekstualisasi Doktrin Islam dalam Sejarah (Jakarta: Paramadina, 1994).

Abu Abdillah al-Bukhari, Shabîh Bu Bukhârî (t.k: Dâr al-Mathba'ah al-Sya'bî, t.th.).

Abu Husain Muslim, Shabîh Muslim, ter. AD Hanie (Yogyakarta: Penyiaran Islam, 1962).

Ahmad Kamal Abu Majd, "Islam dan Tatanan Dunia Global: Terorisme atau Humanisme?" dalam Zuhairi Misrawi dan Khamami Zada, Islam Melawan Terorisme (Jakarta: LSIP, 2004).

al-Jurjânî, Al-Ta'rîfât (t.k:t.p, 1938).

al-Râghib al-Asfahâni, Mu'jam Mufradât Alfâzh al-Qur'ân (t.k: t.p., t.th.).

Asep Rakhmat Fadjar dan Rudy Satriyo, Kompas, Senin, 15 Mei 2006.

Budhy Munawar-Rahman, Islam Pluralis: Wacana Kesetaraan Kaum Beriman (Jakarta: Paramadina, 2001).

Farid Esack, Quran, Liberation and Pluralism: An Islamic Perspective of Interreligious Solidarity Against Oppression (Oxford: Oneworld, 1997).

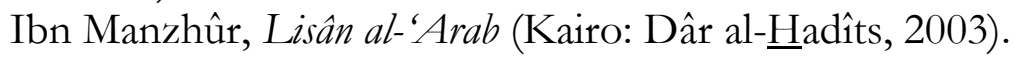

Ibnu Hamzah al-Husainî al-Hanafî al-Dimasyqî, Asbâb al-Wurûd: Latar Belakang Historis Timbulnya Hadis-hadis Rasul, ter. HM Suwarta Wijaya (Jakarta: Kalam Mulia, 1997).

Ismail Saleh, Hukum dan Ekonomi (Jakarta: Gramedia, 1990). 
Jawahir Thonthowi, Islam, Neo Imperialisme dan Terorisme Perspektif Hukum Internasional dan Nasional (Yogyakarta: UII Press, 2004).

Jc Tukiman Taruna, "Pendongkrak Mutu?" dalam Kompas, Senin, 15 Mei 2006.

Kuntowijoyo, Demokrasi dan Budaya Birokrasi (Yogyakarta: Bentang, 1994). , Identitas Politik. Umat Islam (Bandung: Mizan, 1997). , Muslim tanpa Masjid (Bandung: Mizan, 2000).

M. Amin Abdullah, "Rekonstruksi Metodologi Studi Agama dalam Masyarakat Multikultural dan Multirelijius", Pidato Pengukuhan Guru Besar Ilmu Filsafat IAIN Sunan Kalijaga Yogyakarta, 13 Mei 2000.

\section{Keislaman Kontemporer (Bandung: Mizan, 2000).}

M. Quraish Shihab, Membumikan al-Quran (Bandung: Mizan, 1992).

Majalah Intisari Nomor 216, Juli 1981.

Majelis Tarjih dan Pengembangan Pemikiran Islam PP Muhammadiyah, Tafsir Tematike al-Quran tentang Hubungan Sosial Antar-umat Beragama (Yogyakarta: Pustaka SM, 2000).

Majid Ali Khan, Mubammad Saw. Rasul Terakbir, ter. Fathul Umam (Bandung: Pustaka, 1985).

Majma' al-Lughah al-'Arabiyyah, al-Mu'jam al-Wasith (Kairo: Maktabah al-Syuruq al-Dawliyyah, 2004).

Mr. Soepardjo dkk., Manusia dan Masjarakat Baru Indonesia (Djakarta: Departemen PP dan K, 1960).

Muhammad Fuad 'Abd al-Bâqî, Al-Mu'jam al-Mufahras li Alfâz̆h al-Qur'ân al-Karîm (Kairo: Dâr al-Hadîts, 1991).

Muhammad Husain Haekal, Sejarah Hidup Mubammad, ter. Ali Audah (Jakarta: Pustaka Jaya, 1980).

Muhammad Imarah, Islam dan Pluralitas: Perbedaan dan Kemajemukan dalam Bingkai Persatuan (Jakarta: Gema Insani Press, 1999). 
Munawar Ahmad Anees dalam Ziauddin Sardar dan Merryl Wyn Davis (ed.), Wajah-wajah Islam, ter. A.E. Priono dan Ade Armando (Bandung: Mizan, 1992).

Murtadha Muthahhari, Jihad, ter. M. Hashem (Bandar-Lampung: YAPI, 1987).

Musa Asy'arie, "Konstitusi dan Kemandekan Budaya Politik", Kompas, 24 September 2002.

Satjipto Rahardjo, "Hukum Itu Perilaku Kita Sendiri”, Kompas, 23 September 2002.

Sayyid Sabiq, Fikih Sunnah, ter. Kamaluddin A. Marzuki (Bandung: Al-Ma'arif, 1987).

Sukarno, Tjamkan Pantja Sila! Pantja Sila Dasar Falsafah Negara (Jakarta: Pradnja Paramita, 1964).

Sukidi, Teologi Inklusif Cak Nur (Jakarta: Penerbit Kompas, 2001). Tamrin Amal Tomagola, "Berperikemanusiaan, tetapi Tidak Adil”, Kompas, Senin, 15 Mei 2006.

TB Ronny Rahman Nitibaskara, "Super White Collar Crime", Kompas, 1 Oktober 2002.

Wahhbah al-Zuhayli, Al-Fiqh al-Islâmî wa Adillatubu (Damaskus: Dâr al-Fikr, 1989).

Walter Abbott (ed.), The Documents of Vatican II (New York: Association Press, 1966).

William Chang, "Konsensus Rasional atas Masalah Moral", Kompas, 29 Mei 2002.

Yusuf Qardhawi, Pendidikan Islam dan Madrasah Hasan al-Banna, ter. Bustami A. Gani dan Zainal Abidin Ahmad (Jakarta: Bulan Bintang, 1980). 